material. Our research was supported by a grant from the Belgian NFWO.

Received June 25 and September 17, 1984

1. Ishikawa, H.: Comp. Biochem. Physiol 58 B, 1 (1977); Cammarano, P., Pons, S., Londei, P.: Acta Biol. Med. Germ. 34, 1123 (1975); Londei, P., et al.: Comp. Biochem. Physiol. 73 B, 423 (1982); Cammarano, P., et al.: ibid. $73 B, 435$ (1982)

2. Bielefeld, M., Gellissen, G., Spindler, K.D. : Naturwissenschaften 71,152 (1984)
3. Peattie, D.: Proc. Nat. Acad. Sci. USA $76,1760(1979)$

4. Veldman, G.M., et al. : Nucl. Acids Res. 9, 6935 (1981)

5. Hassouna, N., Michot, B., Bachellerie, J.P.: ibid. 12, 3563 (1984); Chan, Y.-L., Olvera, J., Wool, I.G.: ibid. 11, 7819 (1983); Ware, V.C., et al.: ibid. 11, 7795 (1983)

6. Brosius, J., Dull, T.J., Noller, H.F. : Proc Nat. Acad. Sci. USA 77, 201 (1980); Douglas, S.E., Doolittle, W.F.: Nucl. Acids Res. 12, 3373 (1984)

\title{
Das erste Interalkalimetallsulfid: KLiS
}

\section{H. Sabrowsky und A. Thimm}

Lehrstuhl für Anorganische Chemie I der Ruhr-Universität, Arbeitsgruppe Festkörperchemie, D-4630 Bochum

Interalkalimetallchalkogenide waren bis vor kurzem noch völlig unbekannt. Nachdem uns die Darstellung und Charakterisierung erster ternärer Interalkalimetalloxide [1] gelungen war, konnten wir nunmehr bei der Untersuchung des Systems $\mathrm{K}_{2} \mathrm{~S} / \mathrm{Li}_{2} \mathrm{~S}$ als erste Interalkalimetallsulfidverbindung KLiS charakterisieren. Es läßt sich darstellen durch wiederholtes mehrtägiges Tempern äquimolarer Gemenge aus $\mathrm{K}_{2} \mathrm{~S}$ und $\mathrm{Li}_{2} \mathrm{~S}$ bei $970 \mathrm{~K}$ in verschlossenen Korundröhrchen, die unter Argon in Duranglas-Ampullen eingeschmolzen sind. Wichtig bei der Präparation ist eine senkrechte Ausrichtung der Röhrchen während des Temperns, um Reaktionen mit der Gefäßwand zu ver- hindern. KLiS bildet gelblich durchscheinende, äußerst hygroskopische Kristalle. Nach Pulver- und Einkristallaufnahmen kristallisiert $\mathrm{KLiS}$ tetragonal mit den Gitterkonstanten $a=431,8(1), c=696,2(7)$ pm mit $Z=2$ Formeleinheiten in der Elementarzelle $\left(V_{\mathrm{M}}=39,08 \mathrm{~cm}^{3} \mathrm{~mol}^{-1} ; d_{\mathrm{cxp}}=\right.$ $\left.2,33 \mathrm{~g} \mathrm{~cm}^{-3} ; d_{\mathrm{rö}}=2,40 \mathrm{~g} \mathrm{~cm}^{-3}\right)$. Als mögliche Raumgruppe kommt nur $P 4 / n m m$ oder $P \overline{4} m 2$ in Frage, während die binären Ausgangskomponenten kubisch in der Raumgruppe $F m 3 m$ kristallisieren.

Eingegangen am 3. September 1984

1. Sabrowsky, H., Schröer, U.: Z. Naturforsch. $37 b, 818$ (1982)

\section{Evidence for an Extracellular Lytic Compartment of Plant Cell Suspension Cultures: the Cell Culture Medium}

M. Wink

Institut für Pharmazeutische Biologie der Technischen Universität, D-3300 Braunschweig

Vacuoles constitute a characteristic feature of mature plant cells. It has been well established that vacuoles contain most of the cells' hydrolytic enzymes and also store many primary and secondary metabolites [1-4]. To summarize the vacuolar functions Matile [1-3] has coined the terms "lytic compartment" and "toxic compartment". Evidence is presented in this communication that substantial amounts of vacuolar enzymes are secreted into the culture medium by suspension-cultured plant cells. Therefore the medium might function as an extracellular lytic compartment, which is potentially capable of degrading cellular constituents and natural products.

Besides amylase [5], peroxidase [6], nuclease and RNase [7] cell culture media of lupins, in which Lupinus cells have been kept for more than a week, contain a series of other distinct hydrolytic and oxidizing enzymes (Fig. 1), whose activities range between 0.1 and 1.8 $\mu \mathrm{kat} / \mathrm{l}$ medium. Most of these enzymes are thought to be typical for plant vacuoles (Table 1) $[2,4,8]$ or animal lysosomes [10] and have in common that they are catabolic enzymes. To rule out that these enzymes were derived from dead cells, the distribution of the enzymes between the cells and the culture medium was studied. As can be seen from Table 1 typical cytoplasmic enzymes, such as malate and glutamate dehydrogenase could only be recorded from the cells, whereas typical vacuolar enzymes, such as acid phosphatase, esterase and phosphodiesterase are also present in the culture medium. Together with the observation that the cell suspension cultures consisted of healthy photomixotrophic cells, which contained less than $5 \%$ dead cells according to a light microscopic control, we can conclude that the enzymes are probably secreted into the culture medium. A similar assumption has been reached for peroxidase, which is secreted into cell culture media in a lightand calcium-mediated process $[6,11]$. We could record these lytic enzymes in culture media of 12 plant species including Lupinus, Cytisus, Genista, Laburnum, Sophora, Symphytum, Conium, and Daucus. Therefore we assume that the occurrence of catabolic enzymes in cell culture media is a general, though rather unknown feature of suspensioncultured plant cells. However, a similar finding has been reported from animal fibroblast cultures, which release lysosomal enzymes into their culture media [10].

If we consider the catalytic properties of the enzymes found in the culture medium we can assume that most of them are involved in the breakdown of primary metabolites. Furthermore peroxidases are known to degrade a variety 